European Journal of Pragmatism and American Philosophy

III-2 | 2011

Pragmatism and the Social Sciences. A Century of Influences and Interactions, vol. 1

\title{
Continuing the Conversation
}

\section{Richard Bernstein}

\section{(2) OpenEdition \\ 1 Journals}

Electronic version

URL: http://journals.openedition.org/ejpap/844

DOI: 10.4000/ejpap.844

ISSN: 2036-4091

Publisher

Associazione Pragma

\section{Electronic reference}

Richard Bernstein, "Continuing the Conversation », European Journal of Pragmatism and American Philosophy [Online], III-2 | 2011, Online since 29 December 2011, connection on 03 May 2019. URL: http://journals.openedition.org/ejpap/844 ; DOI : 10.4000/ejpap.844

This text was automatically generated on 3 May 2019.

\section{(c) $(1)$}

Author retains copyright and grants the European Journal of Pragmatism and American Philosophy right of first publication with the work simultaneously licensed under a Creative Commons AttributionNonCommercial-NoDerivatives 4.0 International License. 


\title{
Continuing the Conversation
}

\author{
Richard Bernstein
}

1 I have consistently argued that the pragmatic tradition is enriched by the contribution of a plurality of voices. So I want to thank the contributors to this symposium for engaging with my work. I would like to begin my response with two general remarks. Although I have always identified myself with the pragmatic tradition, I have felt uneasy with the label "pragmatism." And the reason is straightforward. As soon as we speak of any "ism" we are tempted explicitly (or implicitly) to specify the core conceptions or key theses that distinguish one "ism" from another. And too frequently we can end up with clichés at a high level of abstraction or with myths that smooth over complexities. This is especially true when we use the term "pragmatism" to designate the entire corpus of thinkers like Peirce, James, and Dewey (or others included in the pantheon of "classical" pragmatism). Peirce thought his categories of Firstness, Secondness and Thirdness as well as his semiotics were absolutely central to his pragmatism (pragmaticism). But I don't think James - despite his generous acknowledgment of Peirce as the founder of pragmatism had any deep understanding of what Peirce was up to and why he placed so much emphasis on logic. At times, Peirce hoped that philosophy would become a "rigorous science." This is the last thing in the world that James desired or thought possible. Pluralism stands at the heart of James thinking but Peirce rarely speaks about pluralism. James and Dewey hoped to change the direction of philosophical inquiry so that it would focus on the vitally important topics of human beings. For Peirce the most vitally important topic is logic - and he thought that Dewey did not understand the first thing about logic. From his earliest days Dewey was deeply concerned with the social, political and education problems of his time, as well as the promise and threats to democracy. One can read pages and pages of Peirce without having the slightest clue that he was directly concerned with these topics. One can easily continue noting "irreconcilable differences" among those that we take to be the founders of pragmatism. So I simply do not believe that there is a hard conceptual core of pragmatism. I am skeptical about "the identity of its conceptual boundaries" because these are constantly being challenged, transgressed, and renegotiated - and this has been true from the very beginning of American pragmatism. This raises a larger issue: Who is included and excluded from the American 
pragmatic tradition. Does it include Jane Addams, Josiah Royce, George H. Mead, Horace Kallen and Alain Locke? Various commentators have developed strong arguments for including each of these thinkers (and others) in the pragmatic canon. (This is why I use scare quotes when I speak of "classical" pragmatists.) Does it make sense to speak, as Robert Brandom does, of Hegelian, Heideggerian, Wittgensteinian, and American pragmatism? It is plausible if one takes seriously Brandom's thesis that pragmatism's "core" thesis is the primacy of social discursive practices that generate norms. Yet some thinkers who identify themselves with the pragmatic tradition have been outraged by Brandom's dismissal of the concept of experience. So rather than listing a set of theses that constitute the conceptual core of pragmatism or drawing up a list of those figures who are to be included or excluded in the canon, I have argued that we should do what Wittgenstein suggests - that we "look and see" in order to focus on themes that are philosophically prominent and are loosely woven together in the thinkers that we tend to group in the pragmatic tradition. And we should be honest about the conflicts and blatant contradictions that we discover among those that we take to be the founders of pragmatism. This is what I have attempted to do. At various stages in my career I have listed some of these central themes - themes that are worked out in very different ways by different pragmatic thinkers. For example in my 1988 APA presidential address, I listed five themes: anti-foundationalism; fallibilism; the nurturing of critical communities of inquirers; sensitivity to the radical contingency and chance that mark the universe including our everyday lives; and irreducible plurality of perspectives and orientations. Today if I were drawing up such a list I might emphasize different themes. And given my pluralistic outlook, I recognize that other have (and will) emphasize still different themes in this tradition. I welcome this diversity as long as one is prepared to defend one's "take" on pragmatism with good reasons (of course, "good reasons" themselves can always be contested).

2 The "pull" of professional philosophy is still towards epistemological, semantic, and conceptual issues that have preoccupied academic philosophers. James and Dewey were apprehensive about such a development. There is a danger that philosophy (including pragmatism) may become more and more irrelevant to what Dewey called the "problems of men" - the cultural, ethical, economic, and political problems of everyday life. My hope is that a younger generation will renew this important critical dimension of the pragmatic tradition. Remember that Dewey always thought that philosophy's primary task is to engage in imaginative criticism. In The Pragmatic Turn I wanted to show that if we focus on themes rather than labels the entire philosophic landscape takes on a different appearance. Labels like "pragmatism," "analytic philosophy," "the linguistic turn," "continental philosophy" are not illuminating; they obscure the prominence of shared thematic concerns.

3 This brings me to my second general comment. Most of these papers touch on the discussion of the pragmatic turn and the linguistic turn - and the relation of "pragmatism" to "analytic philosophy." I am fully aware of battles and wounds that are in the background of these discussions. I began my work on Dewey in the 1950s at a time when Dewey and the pragmatists were considered completely passé. Many of those dedicated to keeping alive the "classical" tradition of the pragmatic thinkers were marginalized in the profession. They were not invited to give papers at our professional meetings, they were excluded from the most prestigious jobs in universities, and they did not receive grants from prominent foundations. And to this day there are those who 
think of themselves as pragmatists who suspicious about anything that smacks of "analytic" or "linguistic" philosophy, just as there are those who think that their favored version of "analytic philosophy" is the only game in town. What is perhaps even more disturbing is that these battles have broken out among those who identify themselves with the pragmatic tradition. We now have Peircians, Deweyeans, and Jamesians fighting among themselves. It makes eminent good sense someone will be more attracted to, and inspired by, his favored pragmatic thinker. But we tend to forget that, despite the strong differences among Peirce, James, and Dewey; they were in philosophic conversation with each other - and learned from each other. For some defenders of the "classical" tradition the villain is Richard Rorty. Critiques of Rorty's understanding of pragmatism have become a culture industry. For others there is deep suspicion about his student Robert Brandom - who looks like a hard core analytic philosopher dressed up in flimsy pragmatic garments. Sometimes this opposition is sloganeered as "experience vs. language." Sarin Marchetti rightly speak of my "debunking" of the "improving" and the "incompatibility" accounts of pragmatism and analytic (linguistic) philosophy. I have always made a sharp distinction between what I call "analytic ideology" and what philosophers who are classified as analytic philosophers actually do. I have no patience with the ideological arrogance of those who think that analytic philosophy is the only game in town or who think that anyone who has not made the "linguistic turn" is simply not really to be taken seriously as a philosopher. And I am also critical of those who think of the texts of the early pragmatic thinkers are the holy writ to be preserved, guarded and embalmed. I think that so-called "linguistic turn" is a myth - a deeply misleading myth that needs to be debunked because when we "look and see" we discover the most diverse and frequently incompatible understandings of language and what the "linguistic turn" even means. In my chapter "Experience after the Linguistic Turn" I sought to show this. If we look at the work of Quine, Goodman, Davidson Rorty, Brandom, McDowell (and many others) we can detect refinements of themes that are prominent in Peirce, James, Dewey, and Mead (of course there are striking differences too!). The point is to do justice to both common themes and differences). I also emphatically believe that that there is a richness and diversity of the "classical" pragmatic thinkers that is still not fully appreciated or developed. We have lost something of the bold speculative spirit characteristic of the early American pragmatic thinkers.

Let me turn to some specific points raised by my interlocutors, I am grateful to Ramón del Castillo and Sarin Marchetti for setting the context for The Pragmatic Turn in the larger context of work by it relating to Praxis and Action as well as several of my essays. Castillo nicely captures the sense of the slightly "tumultuous" polyphonic playful (but serious) conversation that I take to be a feature that has been (and continues to be) vital for keeping the pragmatic tradition alive. I still endorse McIntyre's characterization of a tradition as embodying the narrative of an argument, which is in conflict with other argumentative retellings. Marchetti is sensitive to the ethical reflections that pervade the essays in The Pragmatic Turn and has been a prominent concern in all my philosophic writing. I would simply like to add two points. I frequently speak of "the ethical-political" because, like Aristotle and Dewey, I think they are inseparable. I agree with what Marchetti means when he says that "moral reflection should be a descriptive exercise, in which we challenge those frames of mind that impede us to have a genuine grasp of moral life." But this can be properly done only if one has a larger vision of the ideals that we seek to achieve in our moral, ethical, and political lives. Although I have expressed my reservations about Habermas's Kantian pragmatism, I have always thought that he plays a 
role in Europe - especially Germany - that is comparable to the role that Dewey played in the United States during the early decades of the twentieth century. Drawing on his philosophic concerns - significantly influenced by the American pragmatic thinkers - he has been a public intellectual addressing the issues of his times in the best Deweyean tradition. So although I agree with Marchetti that philosophic reflection should clarify our moral practices, it is not sufficient to be "descriptive" and "therapeutic." Or rather these tasks demand the development of a critical vision. This is why I have always been drawn to the emancipatory features of Frankfurt critical theory.

I find that I am close in spirit to many of the positive points that James R. O'Shea makes. I think that he slightly misinterprets my remarks about "correspondence." My intent was to show that there are features of our ordinary ways of talking that seem to invite some version of a philosophic correspondence theory of truth. I never wanted to deny the inference is involved in perceptual knowledge. This is precisely what I take to be one of the great virtues of Peirce's analysis of perception. And I agree that if challenged about any knowledge claim (including perceptual knowledge), we are required "to give reasons if the question arises." of course, we need more than Secondness to do justice to "realistic intuitions": we also need Thirdness. Or to use the Sellarsian terminology we need to carefully distinguish the impact of causation from the justification of epistemic claims. I think that O'Shea and I disagree about Sellars' "scientific realism." I have never been convinced by the way in which Sellars stages the clash of the scientific and manifest images. And I find Sellars' theory of "picturing" extremely problematic. I am skeptical about Sellars' "unified notion of truth as correct semantic assertability" for reasons that have been developed by McDowell and Brandom. And I also think that the way Sellars speaks of "different domains of truth" is open to criticism. Here I simply want to register my reservations. Developing and justifying them would require a much more extensive discussion. What I welcome on O'Shea's discussion (and in his book on Sellars) is the way in which he clearly places Sellars in the pragmatic tradition.

6 Let me conclude by commenting on a remark by Roberto Frega. He quotes my sentence "Peirce opened a new way of thinking that is still being pursued today in novel and exciting ways by all those who have taken the pragmatic turn." He then comments that surprising this "sea change" consists of "the fact of having found a via media between a dogmatic appeal to the given and an unacceptable frictionless coherentism." This is a serious misunderstanding. The importance that I ascribe to Peirce's early essays is that he had a profound insight into what was wrong with much of modern philosophy from Descartes to the present. And what was required is a rethinking of philosophy - a rethinking that has epistemic, metaphysical, ontological, cosmological, social, ethical and political consequences. The "classical" pragmatists shared Peirce's sense of the need for a reconstruction of philosophy in all its dimensions - although they came to this understanding by different routes. As I suggested in my Prologue, this sense of rethinking philosophy - although it had its independent sources - is shared by Wittgenstein and Heidegger. That is why, despite irreconcilable differences, which should not be ignored, we discover common themes in so much of philosophy during the past 150 years. If I focus on these common themes it is because they are too frequently ignored or distorted by the barriers we artificially establish between different philosophical schools and traditions. I want to reiterate that The Pragmatic Turn consists of a series of essays - a series of snapshots. Although I did focus on the ethical consequences of James' pluralism and Dewey's democratic concerns, I would never want to suggest that this was their only - 
or even their most important - contribution to the vitality of the pragmatic tradition. I hope this is clear from my other writings on these pragmatic thinkers. Finally I think the fact that commentators includes a Spanish, two Italian philosophers and one working in an Irish university exemplifies my thesis that "today there is a much more vigorous, extensive, and illuminating global discussion of the multifaceted aspects of pragmatism that at any time since its origins."

\section{AUTHOR}

\section{RICHARD BERNSTEIN}

The New School for Social Research

bernster[at]newschool.edu 